\title{
Folklore from North Ceylon
}

\author{
J. P. Lewis M. A.
}

To cite this article: J. P. Lewis M. A. (1895) Folklore from North Ceylon, Folklore, 6:2, 176-185, DOI: $10.1080 / 0015587 X .1895 .9720297$

To link to this article: http://dx.doi.org/10.1080/0015587X.1895.9720297

曲 Published online: 14 Feb 2012.

Submit your article to this journal $\pi$

Q View related articles ¿ 


\title{
FOLKLORE FROM NORTH CEYLON.
}

\author{
BX J. P. LEWIS, M.A.
}

DURING the eighteen months in $1889-1890$ that I was in official charge of a part of the Northern Province of Ceylon known as "the Vanni," I came across a few items of folklore which I send you." The Vanni was in the time of the Sinhalese kings a flourishing district; but with the Tamil invasion six hundred years ago, and the consequent destruction of the large irrigation works constructed by the Sinhalese kings, it fell into decay, and has now a population of between fifteen and sixteen thousand, or eight to the square mile. The great majority are Tamils, but there are about a thousand Sinhalese in the extreme south of the district. There are only seventy-five females to every hundred males.

The Tamils are nearly all Saivites and the Sinhalese Buddhists; but the favourite god of the villagers of both races is Pillaiyãr or Ganesa, ${ }^{1}$ the elephant-headed son of Siva and Durga, and god of wisdom and fortune. The people are much devoted to his culte, and on the brink of nearly every tank is to be found a shrine dedicated to him. A broken pillar or head of Buddha or the figure of an elephant sometimes serves to represent the god, or the shrine is indicated merely by a large tree with a trident stuck in front.

Villages are abandoned both by Tamils and Sinhalese because the site is supposed, to be haunted by devils or subject to the anger of Pillaiyar or otherwise unlucky. Some Sinhalese villagers attributed the great mortality in

" And on the middle porch god Ganesha-

With disc and hook-to bring wisdom and wealth

Propitious sate, wreathing his sidelong trunk."

Light of Asia, bk. ii. 
their village to the fact that there was no Buddhist priest resident there, and consequently got a priest from the adjoining province. After his arrival they say the mortality ceased.

There is considerable belief in charms and witchcraft. Ulcers and other diseases or misfortunes are attributed to sorcery.

On one occasion an ola ${ }^{1}$ was found fixed on a gate with an invocation to Siva written under a mystical figure, the object of the charm being to cause a separation between the inmate of the house and his wife. The official then in charge of the district records that "acts of this kind are of frequent occurrence and the village people freely believe in their efficacy." He appears to have thought the practice a serious one and to have endeavoured to put a stop to it, for not long afterwards he seized what he calls "about nine hundred diabolical olas" in the possession of a man addicted to witchcraft, and bound him over to keep the peace.

Cases of trial by ordeal sometimes occur. On one occasion a man charged with stealing a gun was induced to dip his hand into a pot of boiling ghee, in order to prove his innocence by doing so unhurt. He was of course badly scalded and had to go to hospital for some days. He asserted that he had been compelled by threats to adopt this mode of clearing himself; but, on the other side, it was said that he had done it voluntarily, and in fact at the suggestion of his mother.

- The belief in such cures for snake bites or obstinate disorders as the reading of Skanda Purānam (a sacred book of the Hindus) is universal. Another cure for snake bite is a mixture of earth and ashes from the Nakka Tampiran temple at Nayinativu, on an island north of the district. "If this mixture be dissolved in water and drunk in the belief that it will effect a cure, it will cure. Many cases of poisoning

- A palm leaf for writing on. The charm is figured infra, p. 185. 
have been cured in this way." The clay taken from a hole in the floor of the church at Madu is also used for the same purpose. It is considered a specific in cases of snake bite, and is generally known as kovil maruntu, or " church medicine."

During an outbreak of cholera in the district the women took refuge in the temples "to sanctify themselves."

Superstition is not confined to one class or religion. " $\mathrm{A}$ villager who did not like subscribing for a Pillaiyār image, suggested to the Roman Catholic priest to throw it into the tank, which was accordingly done. : The Moormen (Mohammedans), however, after a time ascribed some cases of illness to the indignity done to the image, and begged that it might be set up again, which has been done."

The Roman Catholic congregation at Mullaittivu, the chief village in the district, were not at all pleased at my shooting, at the request of the priest, an immense cobra which had taken up its abode in the church, because they said it was a kovil pämpu, or " church snake."

The annual festivals on moonlight nights at celebrated shrines, whether Hindu or Roman Catholic, attract crowds of people, who encamp in the jungle round about, and at night sleep on the ground in the neighbourhood of the sacred places. The most important of these is the Madu festival, which is attended by Roman Catholics, Hindus, Buddhists, and Mohammedans alike. The origin of the sanctuary is lost in antiquity.. It existed before the Dutch took posses. sion of the island, since Baldcus makes mention of it as a famous shrine celebrated by its earth, which, he adds, is said to cure the bites of venomous serpents. It owes its origin probably to the persecutions of the Christians by the King of Jaffna, some of them together with a few priests having taken refuge, in the jungles at Madu, which was then on the borders of the King of Kandy. However, it was only at the beginning of the "seventies". that the pilgrimage was regularly organized. Since then it has 
always been progressing. During some years not less than thirty thousand persons have visited the shrine. The festivals begin on the Ist of May, or on the first Sunday of May, and continue until the beginning of October. At the end of June, however, and the beginning of July the pilgrims flock together in greater number than usual. Sometimes over 5,000 have met together at the festival which is celebrated on the 2nd of July. In $189^{\circ}$ the number of persons who visited the shrine from the Ist of March to the Ist of October was over 25,000.

The most interesting ceremony at this festival is the distribution of rice to the pilgrims on the last day of the festival. The following is a description of it from an official diary :-

"Fuly 2.-The last day of the festival. A special service and a general procession round the church in the morning. Then the preparations for the pitchaisoru (i.e. "alms-rice") began-wholesale cooking of rice and curry by women volunteers - the materials having been collected yesterday, each pilgrim depositing his or her contribution of rice, vegetables, curry-stuffs, \&c., under a certain tree. The day is spent by the pilgrims in packing up their carts and preparing for a start. At about 4 p.m. the bell rings, and all the pilgrims assemble in the open outside the church and seat themselves in rows, each with a basket, chatty, or plate in front of him. I suppose this is about the only occasion in which caste prejudices are set aside-people from all parts of Ceylon and from India sit down to a meal side by side, perfectly satisfied as long as those who distribute the rice are of high caste. During the distribution every one is quiet (except perhaps the babies), and no one moves from his place. Rice and two kinds of curry are given to all, and then the bell rings for the blessing, the pilgrims kneel, the priest pronounces the blessing, wishes them good health and good luck, and then comes a stampede. Every one takes up his rice and curry and is off, and 
within a quarter of an hour the road in both directions presents a stream of people and carts on their homeward march (there is no disorder and no rowdyism), and by the next morning the place is almost deserted."

The chief Hindu festival is at the Vattappalai temple of Kannakai Amman, a few miles from Mullaittivu. Kannakai Amman was the daughter of a Madura chief, who became celebrated on account of her sanctity and miraculous powers, and who for a time made the Vanni her head-quarters soon after it was colonised from India. She is the patron especially of the Chetty caste, and is supposed to have power over small-pox. She corresponds, I presume, to the goddess Sitala of Northern India, and she is known to the Sinhalese as the goddess Pattini. The tradition is that she left her husband on account of his unfaithfulness, as she found that he had given her anklets to some dancing girls, and went over to Ceylon. When she arrived at what is now the site of the Vattappalai temple she saw a man engaged in ploughing, and asked him for a drink of water. He left his plough and went to fetch it. On returning he missed his plough; the visitor had turned it into a margosa tree (Azadirachta Indica), the plough having been of that wood. The tree is still shown near the temple, and what better proof can there be of the truth of the story?

I was present at this festival on the night of and June, 1890. The temple is situated on the shores of a lagoon on the north-west coast, and is a-mere shed. It was midnight and full moon when we arrived. There were about 3,000 or 4,000 people assembled, including a number of Sinhalese from the next, province, who are quite as anxious as the Tamils to obtain for themselves whatever immunity from disease and misfortune attendance at this annual festival can afford. . Most of the people were lying about in all directions asleep awaiting the time of puija (worship).

The most curious spectacle of the festival was the dancing 
"of an old man known as Kattādi Udaiyar," whose office it is to dance in honour of the goddess. This office is hereditary in his family. He is supposed during these performances to be possessed. After the Brahmins had finished their $p \tilde{u} j a$ he came and stood before the entrance to the temple under a canopy consisting merely of a strip of white cloth supported by two sticks. He then tied some pieces of different coloured cloth together and succeeded in making a sort of doll, which he carried in his left hand during the performance which followed. The tom-toms now starting a low continuous rumbling he set off on a violent tremble, keeping, as it were, in time to the tomtoms, and his whole body shaking in the most extraordinary manner. When he had shaken sufficiently long and arrived at a climax, the tom-toms at the same time accelerating their pace, he threw a handful of rice in the air. This he repeated two or three times in the direction of each quarter, turning to each of them successively, beginning with his face to the temple. The people believe that this rice never returns to earth, but is caught up in the air by the goddess. The fact is, each handful is nearly all shaken out of his hand before he considers himself sufficiently worked up to throw it. Next, seizing his parti-coloured doll with both hands, he danced about violently, holding it at arms' length and shaking it in every direction as if to worry the life out of it. Finally he placed it in the innermost part of the temple.

This ended the first part of the performance. The next thing was to conciliate the devils by providing offerings for them also. A cloth about a yard square was set out with little heaps of betel, areka-nuts, and rice. The Kattädi then, standing with his back to the temple, held in both hands over the cloth a sort of silver wand. This, it appears, was to warn the devils to be obedient. Next, standing in the same position, he slowly lifted in each

1 Kattādiya in Sinhalese = devil-dancer.

vol. vi. 
hand a burning wick over his head, and finished by flinging them away from him over the cloth. He repeated this action, substituting two rolled-up betel leaves for the wicks. He next went through the process of saluting the devils by putting his hands on his head in the proper attitude for salutation and turning in this position to the four quarters successively, devoting a certain time to each quarter impartially. After this he threw rice to each quarter. While doing this his action was exactly that of a person "putting the weight." An assistant stood behind him holding his left hand behind the Kattädi's right and helping the latter with a shove off each time, while with his right hand he kept rapidly replenishing or pretending to replenish the thrower's hand with rice after each throw. As all this was done very quickly, the effect was that of one man putting an imaginary weight with another close behind him keeping time to and imitating his action. The tom-toms meanwhile kept up the same low rumble (these performances, would have been nothing, without them) the whole time, and the jingle of two bangles held by the Kattädi in his left hand helped to vary the din.

The principal ceremonies performed by the people were those of burning camphor (which was being hawked for their convenience on the spot by Mohammedan traders) and boiling rice on three large pots before the temple. These pots are tied together by a string, and fires are lighted under them in holes dug in the ground. The people believe that this string is never burnt by the fire, also that the lamps in the temple burn with sea-water instead of oil.

There was no disturbance of any kind during the festival, but merely, a little struggling to get a good place, when the pujja began. A switch was then freely used to restore order, but nobody resented it in any way.

It was stated that Mr. Nagel (the Dutch administrator of the Vanni $1783-1796)$ once visited the temple on the festival 
and presented a garland of flowers to it (this was very unlikely under the Dutch Government), and that on this occasion the Kattadi of the time made the large panichchai tree (Diospyras emboyopteris) near the temple dance, since when it has never borne any fruit. This panichchai is of enormous size, it is the largest tree of the kind in the district.

There are other Hindu festivals at different temples in the district, generally in June or July on full-moon day. At one of them it is the ceremony of the bathing of the spear of Kandaswami ${ }^{1}$ which is carried in procession from the temple to a sacred pool for that purpose. The pool is about six miles from the village. It is about a quarter of a mile long and never dries up. The people believe that when the spear is bathed the water rises one foot. This is easily accounted for by the fact that at the same moment as many people as can get into the pond do so. , Pilgrims before bathing throw money into it.

Kandaswami is at one time of the year taken out to hunt deer, a shed for his accommodation being erected in the neighbourhood of the village.

"It is interesting to observe how the seats of the chief temples are still the emporiums of commerce at the festival seasons, when inhabitants of the most distant villages congregate to pray and to purchase." A fair at the next village on the high road follows the festival at Vattappalai, and the road is lined with temporary shops made of coon-nut leaves.

I quote from an official diary ${ }^{2}$ an account of a curious and interesting custom observed on one of the roads :

"Under a naval tree (Eugenia jambolana), at the boundary between [two] villages, every man travelling along the road religiously deposits a stick, while every

1 The god of war, son of Siva.

2 Diary of Mr. E. M. de C. Short, C.C.S., Febriary, 1892, 
woman who passes picks up one from the heap with her foot and throws it away.

"The origin of this custom is given as follows :

"Once upon a time a woman ran away from her husband, and while on her journey sank exhausted on this road. A man pitying her condition lifted her on his 'shoulder and carried her along. A second traveller, in his surprise and contempt at seeing a woman in such a position, put out his tongue at her, which action the woman interpreted as an offer to carry her on his tongue, and she at once proceeded to accept it. The first traveller, annoyed at her ingratitude, left her and departed, the second also decamped, and the woman perished miserably. The heaping up of sticks on the spot where she died marks the males' disapproval of the conduct of a faithless wife. The surreptitious removal with the foot shows womanly sympathy with an erring sister! The custom has existed 'from time immemorial.' Some villagers of the male sex coming behind me deposited their sticks on the heap. "I had not the advantage of witnessing the procedure adopted by female travellers" along this road."

I once noticed two men who, contrary to the usual Tamil practice, were wearing full beards. It was explained that it was the custom of some of the Vanni men to let their beards grow during the time of their wives' pregnancy.

When a youth attains manhood, if he can afford it, he has his ears pierced for earrings, which ornaments he thereafter wears. At the same time his head is shaven, with the exception of a small tuft on the crown, which is allowed to grow long and is tied into a knot: If he cannot afford earrings he has to go with unshaven head, and his hair is then tied into a knot on the side of his head, which gives him rather a quaint appearance. This custom is not peculiar to the Vanni, but is prevalent among all the Tamils of the north of Ceylon. 
NOTE.-The following is a representation of the figure drawn on the charm referred to on page 177 for separating man and wife, with a translation.

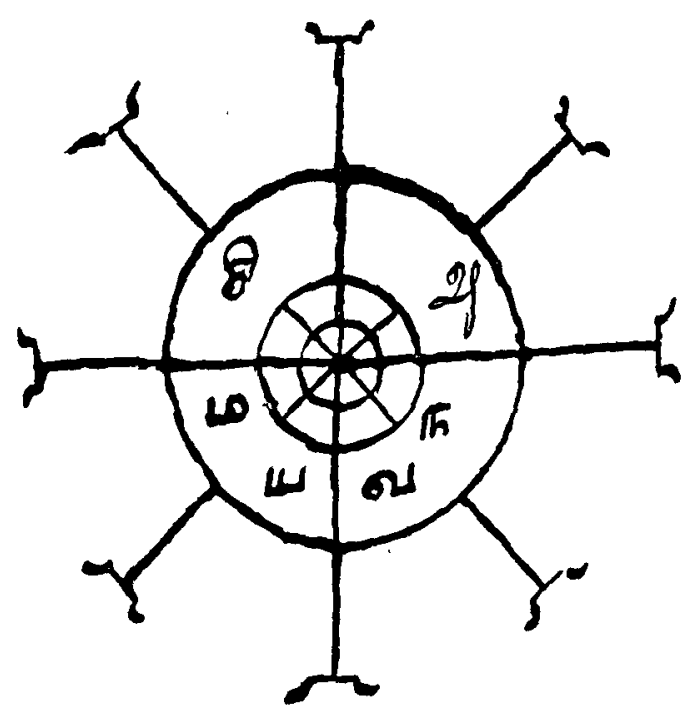

Inside the circle, in Tamil, "May Siva be blessed." Outside, "May Kanapati, son of Katiran, and Abirami, daughter of Silamban, be separated in rage and anger, so that they may not see each other's face. May rage and anger hover about them like the black stork of the black hills. In the name of Siva." 